\title{
変態型磁石合金の磁性と機械的性質の関係*
}

\author{
（永久磁石材料の加工性について一-I） \\ 木 村、康 夫**

\section{Relation between Magnetic and Mechanical Properties \\ of the Transformation-Type Magnet Alloys.}

(On the workability of permanent magnet materials-I)

Yasuo Kimura

\section{Synopsis:}

The materials for permanent magnets exhibit high coercive force and residual induction. The coercive force is called magnetic hardness and materials with high coercive force are in general mechanically hard. The study on the relation between magnetic and mechanical properties of materials for permanent magnets is important of commercial fabrication. The materials now in use are classified metallographically into some groups and these workability is studied. In this paper, quench-hardening magnet steels, $\gamma-\alpha$ transformation magnet alloys and order-disorder transformation magnet alloys are studied.

In quench-hardening magnet steels, coercive force is proportional to square root of the volume of retained austenite and the best value of magnet is obtained, when fine particles of martensite needles are distributed in the retained austenite and the ratio of martensite to austenite is 2 to 1 . The magnet steels are mechanically hard in the quenched state, but are machinable in the annealed state without martensite structure.

In the $\gamma-\alpha$ transformation magnet alloys, $\gamma$ phase transforms to $\alpha$ phase during cold-working and some $\alpha$ phase is converted to $\gamma$ during aging. When $\gamma$ is dispersed highly in $\alpha$, the coercive force of materials increases. In the simple $\gamma-\alpha$ transformation alloys, mechanical hardness decreases lineally with the precipitation of $\gamma$. In the $\gamma-\alpha$ transformation alloys with meta-stable order structure, the mechanical hardness increases rapidly with transformation of disorder $\alpha$ to meta-stable order $\alpha$, but depends hardly upon the precipitation of $\gamma$. These alloys are necessary to machine after cold working and ageing.

In order-disorder transformation magnet alloys, coercive force increases remarkably during aging, but mechanical hardness slightly. The workability of the disordered state is easier than ordered state.

The workable state of transformation type magnet alloys is a disordered $r$ phase-and when this disordered $\gamma$ phase exists in room temperature, the coldworking is possible.

\section{I. 緒 言}

永久磁石材料は残留磁東密度と抗磁力がともに高く， しかも磁気エネルギーが大きいととが望ましい。抗磁力 は磁気的硬さとも呼ばれ一般に抗磁力が高い永久磁石材 料は機械的烦いものである.そこで永久磁石材料は硬 く機械加工が難しいことが工業的に一つの险路となつて いる. 機械加工し易くしかも抗磁力が高い永久磁石材料 が好ましい：永久磁石の磁性と機械的性質との関係を知 ることは工業的にはるちろん，理論的にも重要な問題で 西る.現在使用されれている永久磁石材料を金属組織学的 に分類し，磁性と機械的性質主として譏械的硬さの関係
を研究した結果を述べ，洘察することにする. 抗磁力は介在物の存在または内部応力によつて堌大す る. そこで析出，変態現象などを利用して抗磁力を高く した磁石も亦るし，また磁性材料定微粉末として磁区回 転機構が主役を演ずるような微粉末磁石あある.ここで は永久磁石材料をつぎの 4 つのグループすなるち (1)相 変態硬化磁石合金，(2) 規則一不規則 变態磁石 合金, （3）析出硬化磁石合金抢よび（4）微粉末磁石に分類す ることにする.この論文では相变態硬化磁石と規則一不

* 昭和 34 年 4 月本会講演大会にて発表

** 東京計器紫造所, 工博 
規則変態磁石合金についてのみ考察することにする.

磁性は主として電磁石に試験片をはさんで測定する電 磁石型継鉄式測定装置を用いた1．抗磁力が小さい材料 の場合に泣力計を用いて測定した場合もあるリ。機械 的性質としては主として機械的硬さを測定した。

\section{II. 相変態磁石合金}

このグループに属す る磁石合金は焼入硬化 磁石鋼と炭素を含まな $\checkmark \gamma-\alpha$ 変態磁石合金 の2種類に分けられ る.この 2 種類の合金 の状態図を略図的に示 すと Fig. 1 のように なる.熄入硬化鋼は高 温で安定なオーステナ イト状態より焼入れる

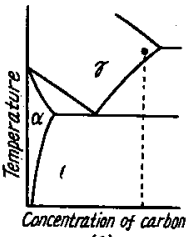

(a)

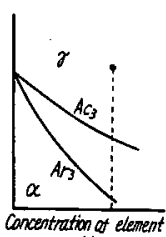

(b)
Fig. 1. Schema of phase diagrams of $\gamma-\alpha$ transformation type magnet alloys - (a) quench-hardening steels and (b) carbon-free $\gamma-\alpha$ transformation alloys.

とマルテンサイト变態を起し抗磁力が上昇する.また崖 素を含末ない $\gamma-\alpha$ 変態磁石合金は高温より急冷すると $\gamma$ 相であるが冷間加工定すると $\gamma$ 相が $\alpha$ 相に変態し，つ きにある温度で時効すると $\alpha$ 相の一部が微細な $\gamma$ 相に変 態するために抗磁力が上昇し磁石特性がよくなる。すず 焼入硬化磁石銅より考察することにする。

\section{(1) 焼入硬化磁石鋼}

鋼を変態点以上の温度から水または油に焼入れると高 温で安定なオーステナイトがマルテンサ、イトに変態す る.この焼入による組織変化により抗磁力が上昇するこ とを利用し古くから Cr 鋼，W 鋼，KS 鋼などが永久 磁石として用いられている. 3 元系鋼でオーステナイト に炭素をるつとも固溶する Al 鋼 (MT鋼) について熱 処理を变化したときの磁性と機械的硬さの関係を明らか にしよらと思う。

さて強磁性相の飽和磁束密度は組織により多少变化す るであらうが一応同一と考える. 非磁性相と強磁性相が 混合しているときに飽和磁束密度 Bs 強磁性相の量 $v$ に比例する。

$$
B s(v)=B s(1) \cdot v
$$

とこで Bs(1) は非磁性相が存在しないときの飽和磁束 密度を示すことにする.

MT 鋼 (Al $8 \%, \mathrm{C} 2 \%, \mathrm{Fe}$ 残) $1200^{\circ} \mathrm{C}$ 加 b油 焟入したとき飽和磁束密度 $B s=6,300$ gauss, 残留磁束 密度 $B r=2,300$ gauss 抗磁力 $H c=300 \mathrm{Oe}$, ビッカー 不硬さVHN は 745 である。焼戻する $B s, B r$ は上昇

するが $H c$ は低下する．また VHN は最大值 840 を通 り低下する2).

飽和磁束密度 $B s$ の值が (1) 式を満足するむのとし て求めた強磁性相の量 $v$ と残留磁束密度 $B r$, 抗磁力 $H c$ および $\mathrm{Br} \times \mathrm{Hc}$ の関係在 Fig. 2 に示した. 残留磁束 密度 $B r$ は飽和磁束密度 $B s$ に比例すると考えられる から $B r と v$ との間には (2) 式が成立すると思われ る.

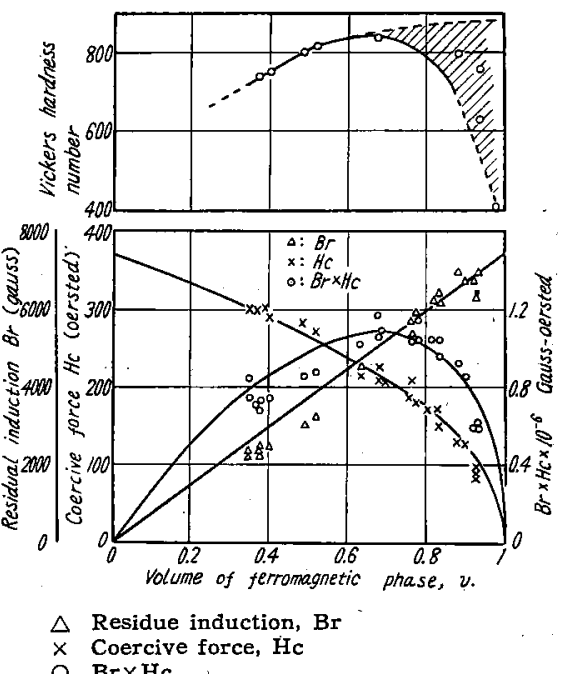

Fig. 2. Relation between volume of ferromagnetic phase $v$, and coercive force $H c$, residual induction $B r, B r \times H c$ and Vickers hardness of MT magnet steel.

$$
B r(v)=B r(1) \cdot v
$$

実際に Fig. 2 に示すように $B r$ ととの間にはBr(1) $=7,500$ gauss とした直線と大体一致する.Kersten ${ }^{8}$ は 小さな棒状の不純物が $(1-v)$ 存在するときの抗磁力 に対して次式を提案した。

$$
H c=2 \cdot 5 p^{\prime} \frac{3 / 2 \lambda Z+b K}{I s} \sqrt{1-v}
$$

ここで $p^{\prime}$ は磁壁の厚さと不純物の平均直径できまる函 数， $\lambda$ 注飽和磁歪， $Z$ は内部応力， $K$ は磁気結晶異方性 常数，Is 恃飽和磁化の強さ，b惊数立それぞれ示す。

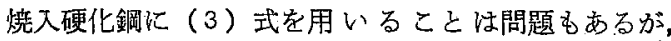
$2 \cdot 5 p^{\prime}(3 / 2 \lambda Z+b K) / I s=H c(0)$ とすれば（3）式は（4) 式で示される.

$$
H c=H c(0) \sqrt{1-v}
$$

$\mathrm{MT}$ 鋼について強磁性相の量 $v$ と抗磁力 $H c$ の值をプ ロットすると測定值は Fig. 2 のように $H c(0)=375$ oer sted とした場合の曲線とよく一致する．MT 鋼以外の 
焼入硬化磁石鋼についてす（4）式は成立する。このよ らに抗磁力を增加させるためには非磁性オーステナイト を残留させる必要がある。しかし強磁性相が少なくては $B r$ が低くなり磁石として㵍題とならない，永久磁石 としては磁気エネルギー $(\mathrm{BH})_{\max }$ が大きいことが望ま しい. 異方性を有しないときには (BH) max が $B r \times H c$ に大体比例する. $B r \times H c$ は（2）式と（4）式から

$$
B r \times H c=B r(1) \cdot H c(0) \cdot v \cdot \sqrt{1-v} \ldots
$$

となる. $B r(1), H c(0)$ は材料によつて定まる. マルテ ンサイトが非磁性オーステナイトに微細に分散し全量の 1/3 非磁性オーステナイトが占めるところで磁石特性 がもつともよい. MT鋼の場合 $B r(1)=7,500$ gauss, $H c(0)=375$ oersted 娄代入すると，

$$
B r \times H c=7,500 \times 375 \cdot v \cdot \sqrt{1-v}
$$

となる.MT鋼のvに対する $B r \times H c$ の測定值は Fig. 2 に示すように (5)' 式の曲線と大体一致している.

機械的硬さは強磁性相がマルテンサイトか，フェライ トかによつて Fig，2 に示すように非常に異なるが大体 の傾向は $B r \times H c$ の傾向に似ている. このことは磁石 特性がもつともよい状態で機械的に硬いという工業的に は好ましくない性質をるつている。しかし焼鈍すれば VHN=300 位になるので，焜鈍状態では孔明加工など の機械加工をおこなうことができる.その後焼入焼戻を おこない所定の磁石特性をうる必要がある，その硬化し た状態ではグラインダー加工しかできないため加工は制 限される。

\section{（2）炭素拿まない $\gamma-\alpha$ 変態磁石合金}

炭素を舍まない $\gamma$ - $\alpha$ 変態磁石合金は Fig. 1 (b) に 示すような状態図をもつていう.このグループは単純な $\gamma-\alpha$ 変態磁石合金と準安定規則格子をもつ $\gamma-\alpha$ 变態磁 石合金とに分けられる。

\section{1) 単純な $\gamma-\alpha$ 変態磁石合金}

冷間加工可能な $\gamma-\alpha$ 変態を利用した磁石合金にはFe に富んだ $\mathrm{Fe}-\mathrm{Ni}-\mathrm{Cu}$ 系, $\mathrm{Fe}-\mathrm{Mn}$ 系および $\mathrm{Fe}-\mathrm{Ni}-\mathrm{Cr}$ 系 合金などが属する.山本・目黑4は $\mathrm{Fe}-11 \cdot 6 〜 15 \cdot 2 \% \mathrm{Mn}$ 合金を $40 \%$ 冷間压延し， $700^{\circ} \mathrm{C}$ まで各温度で時効した ときの磁性とロックウエル硬さを測定した。 また三島・ 太刀川5将 18-8 ステンレス鋼，および 15\% Cr-12\%Ni$\mathrm{Fe}$ 合金を $90 \%$ 冷間任延後各温度で時効したときの磁性 とビッカース硬さ穵測定した. 例光ば18-8ステンレス銓 老 90\% 泠間圧延したとき残留磁束密度 Br6,700gauss 抗磁力 $H c$ 50 Oersted, VHN 520 であるが時効する と $\mathrm{Br}$ と VHN が低下し，Hc が上㫒する．これら2つ の系では加工前ほとえど $\gamma$ 相であるが任延すると $\alpha$ 相に
変態し,時効すると $\alpha$ 相より非磁珄 $\gamma$ 相が分散析出し,飽 和磁束密度およひ残留磁束密度が減少する. 飽和磁束密 度（または残留磁束密 度) は強磁性相の容積 に比例して変化すると 考光られるから飽和磁 束密度の変化をもつて $\alpha$ 相と $\gamma$ 相の容積変化 を示す量とする． $\mathrm{Fe}$ $\mathrm{Ni}-\mathrm{Cr}$ 系合金の残留 磁束密度，抗磁力和よ びビッカース硬さの関 係を Fig. 3 に示し た. 時効により非磁性 相の増加とともに機械 的硬さは一次的に減少
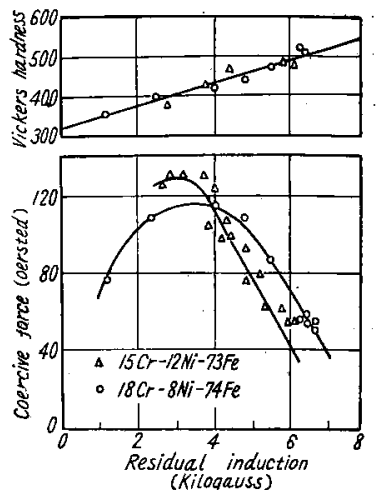

Fig. 3. Relation between vickers hardness, coercive force and residual induction of $90 \%$ cold rolled $\mathrm{Fe}-$ するが，抗磁力はある Ni-Cr alloys.

ところで最高值をすつ曲線を示す，Fe-Ni-Cr 系， Fe$\mathrm{Mn}$ 系合金などのように規則格子が存しない系では機械 的硬さは時効により増加しないで变態にしたがい減少す る.このグループの合金は $\gamma$ 状態のとき冷間巵延が可能 で，しかも時効によつて機械的に硬くならないので最大 の磁性を有する状態で加工することができる。しかし抗 磁力が低く，磁石としての実用性に之しい久点がある。

2) 準安定規則格子をもつ $\gamma-\alpha$ 変態磁石合金

このグループに属する磁石合金には vicalloy があ る. vicalloy は $\mathrm{V}=10 \sim 14 \%, \mathrm{Co}=50 \sim 54 \%, \mathrm{Fe}$ 残 から成る合金で冷間加工 が可能である6 8).1,000

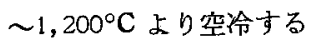
とほとんどケ相であるが 玲間加工すると $\gamma$ 相が $\alpha$ 相に変態する.ついで $500 \sim 700^{\circ} \mathrm{C}$ で時效する と再び $\alpha$ 相のマトリック スからて相が微細に析出 するために抗磁力が上昇 寸る. vicalloy $の$ Vの 一部を Cr でおきかえた $8 \%$ V 2\% Cr 53\% Co$\mathrm{Fe}$ 合金について実駼 L た結果によれば 90\% 冷 間圧延のままで飽和磁束 密度 16,200 gauss,抗磁
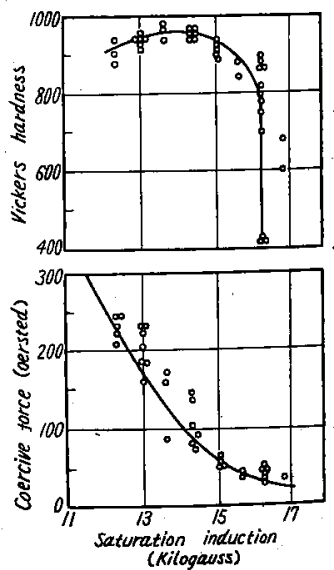

Fig. 4. Relation between Vickers hardness, coercive force and saturation induction of $90 \%$ coldrolled specimen of Vical loy containing chromium. 
力 35 oersted, ビッカース硬さ 416 である9．時効す ると的和磁束密度およで残留磁束密度は減少し, 抗磁力 および機械的硬さは上昇する.この合金を $90 \%$ 冷間圧 延後 $420 \sim 600^{\circ} \mathrm{C}$ の温度範囲で時効したときの飽和磁束 密度，抗磁力抢よびビッカース硬さの関係学 Fig. 4 に 示した. 飽和磁束密度の减少すなわち に抗磁力が上昇することがるかる.非磁性相の析出によ り抗磁力が増加する挙動は Fe-Mo 合金10)の抗磁力の 变化と非常によく似ている.

Néel ${ }^{11}$ は自発磁気が場所場所で不規則的に変化する 場合の抗磁力を理諭的に求めた. 内部応力の項を無視で きる磁気異方性の大きな材料で非磁性相が $v$ だけ存在す るときの抗磁力 $H c$ は次式で示される。

$$
H c=\frac{2 K v}{\pi I s(1-v)}\left[0.386+\log e \sqrt{\frac{2 \pi I s^{2}}{K}}\right]
$$

ここでIs 屾飽和磁化の強さ，Kは異方性常数をそれぞ れ示す.この合金の異方性常数Kは末だ求められていな いが仮定をおいて（6）式より求めた計算值は測定值と 大体一敨する9).

冷間加工した試料で時効初期に飽和磁束密度がほとえ ど変化しないのにビッカース硬さは冷間圧延のままの VHN 418 より約 500 増加してVHN 900 に達する. この現象は単純な $\gamma-\alpha$ 変態である $\mathrm{Fe}-\mathrm{Ni}-\mathrm{Cr}$ 系合金 などには見られない現象で， vicalloy 特有の挙動であ る. 抗磁力が大きく変化する範囲でビッカース硬さの変 化非常にわずかである. 時効による抗磁力の变化とビ ッカース硬さの変化に直接的な関連性のないことがよく わかる. 抗磁力は飽和磁束密度の減少すなわち非磁性相 の析出とともに增加するが，ビッカース硬さは冷間任延 により生じた不規則状態の $\alpha$ 相が規則状態の $\alpha^{\prime}$ 相に変 化する際に内部歪が増加し機械的硬さが増すものと思わ れる. 上述したように冷間加工後一度時効したら加工性 が失われるから泠間加工後適度に曲げ，打抜などの加工 をしその後所定の時効をする必要がある.

\section{III. 規則一不規則变䈍磁石合金}

規則一不規則変態型磁石合金のうち代表 的な合金は FePt'1213) および CoPt14)15)である。高温で安定な不規 則状態の面心立方格子は規則变態点を通過し冷却する と規則化がおきて面心正方格子となる．磁性は成分，冷 却速度，時効温度および時間によつて非常に影響をうけ る(18). 最高の抗磁力は規則化が約半分進んだときにえら れることがX線的研究から明らかである４8原子\% Co$\mathrm{Pt}$ 合金学 $1000^{\circ} \mathrm{C}$ から空冷後 $500 \sim 700^{\circ} \mathrm{C}$ で時効した
ときの電気抵抗, 機械的硬さおよび磁性などを New-

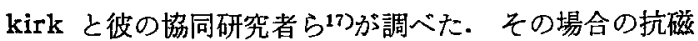
力と機械的硬さの関係をプロットしたところ Fig. 5 の

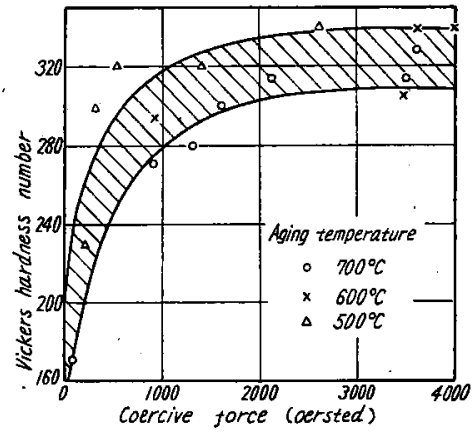

Fig. 5. Relation between Vickers hardness and coercive' force of Co 48 at-\%-Pt alloy.

ような関係があることがかかつた．時効すると不規則格 子と coherentな規則格子が発生するためビッカース硬 さは 180 から 330 の増加するが，割合硬くならない。 しかし抗磁力は 1000 oersted から 4000 oersted と非 常に増加する.このことは多分内部歪が抗磁力上上昇さ せる原因でなく，結晶異方性または形状異方性がその原 因と考えられる. 不規則格子の地に生じた規則格子の相 の大きさと形状およびその分布が適当なとき高い抗磁力 が生ずると思われる.Fig. 5 から明らかなように不規 則状態の方が規則状態よりる軟く延性がある.

\section{IV. 総括}

変態型磁石合金を金属組織学的に分類し，その磁性と 機械的硬さを調べた結果を総括するとつぎのようにな る.

（1）焼入硬化磁石鋼の抗磁力は残留オーステナイト の量の平方根に比例し, 残留磁束密度は残留オーステナ イトの量が増加すると減少する.また磁性の最大値は残 留オーステナイトが全量の $1 / 3$ を占め，微細なマルテン サイトが細く分布したときにえられる。このとき機械的， 硬さもほほ最高になるので孔明などの加工はこの状態で はできないが，マルテンサイトがない焼鈍状態では機械 加工゙が可能である.

(2) $\gamma-\alpha$ 変態磁石合金は泠間加工すると $\gamma$ 相が $\alpha$ 相 に変態する.つういて時効すると $\alpha$ 相から $\gamma$ 相が細く分 散析出する. $r$ 相析出とともに残留磁束密度は隇少し, 抗磁力は上昇する。時効による抗磁力の挙動は Néel の 理論方ら説明される. 単純な $\gamma-\alpha$ 変態磁石合金の機械 的硬さ梳 $\gamma$ 相析出とともに一次的に隇少するので最良の 
磁性がえられる熱処理後加工することが可能である・し かし準安定規則格子を有する $\gamma-\alpha$ 变態磁石合金では機 械的硬さは $\alpha$ 相が準安定規則格子の $\alpha^{\prime}$ 相に变化する際 急激に上昇し， $\gamma$ 相の析出にはほとえど無関係である。 そのため冷間加工後適当な機械加工をしてその後時勃す る必要がある。

（3）規則一不規則変態磁石合金は空冷後時効するこ とによつて機械的硬さの上昇はわずかであるが，抗磁力 は非常に增大する. 不規則状態の方が機械的硬さが軟く 延性がある。

（4）変態型磁石合金の加工しやすい状態は不規則状 態の $\gamma$ 相で，この $\gamma$ 相が常温までもぢきたされた場合に 冷間加工が可能であることが明らかになつた。

(昭和 34 年 6 月寄稿)

交献

1）永久磁石の測定法：計測 8 (1958)，361，429, 502

2) 三島・㢗口・术村：日本金属学会誌, 22 (1958) 63

3) M. Kersten: Phys. Z. 44 (1943) 63

4) 山本 ·目黒：日本金属学会，分科会報告 II (1949) 25

$5 ） 三$ 島·太刀川：日本金属学会誌，20（1956）198
6) E. A. Nesbitt: Trans. AIME, 166 (1946) 415

7) D. L. Martin and A. H. Geisler: Trans. ASM, 44 (1952) 416

8) 三島·太刀川：日本金属学会諾 19 (1955) 685

9) 三島·橋口· 木村：日本金属学会誌 22 (1958) 393

10）三島：橋口・木村：日本金風学会誌 20 (1956), 165

11) L. Néel: Physica 15 (1949) 225

12) L. Graf and A. Kussmann: Phys. Z. 36 (1935) 544

13) H. Neumann: Arch. tech. Messen. (1937) 912

14) W. Jellinghaus: Z. tech. Phys. 17 (1936) 33

15) E. Gebhardt and W. Köster: Z. Metallkunde, 32 (1940) 253

16) D. L. Martin: Conference on Magnetism and Magnetic Materials (1956) 188

17) J. B. Newkirk, A. H. Geisler, D. L. Martin and R. Smoluchowski: Trans. AIME. 188 (1950) 1249

塩基性鋼㳯中の酸化第 1 鉄, 酸化第 2 鉄および

酸化チタンの定量*

（塩基性鋼㳯の化学分析法の研究一II）

\begin{abstract}
若 松 茂 雄**
Determination of $\mathrm{FeO}, \mathrm{Fe}_{2} \mathrm{O}_{3}$ and $\mathrm{TiO}_{2}$ in Basic Slag.

(Study on chemical analysis of basic slag-II)
\end{abstract}

\title{
Shigeo Wakamatsu
}

Synopsis:

This investigation was undertaken to find rapid and accurate chemical methods for the analysis of basic slag. In the report (II), a simple spectrophotometric or volumetric methods is described for determination of $\mathrm{FeO}, \mathrm{Fe}_{2} \mathrm{O}_{3}$ and $\mathrm{TiO}_{2}$ which are contained in basic slag.

Determination of $\mathrm{Fe}_{2} \mathrm{O}_{8}$ : Dissolve the sample with $\mathrm{HCl}$, and dilute to about $100 \mathrm{ml}$. with water. Adjust to $\mathrm{pH} 2 \cdot 0$ with ammonium acetate, and titrate with EDTA using salicylic acid

* 昭和 34 年 4 月本会講演大会にて発表 ** 東都製鎘株式会社技術部 